\title{
VARIJABILNOST POPULACIJA JAVORA KLENA (Acer campestre L.) U BOSNI I HERCEGOVINI PREMA MORFOLOŠKIM OBILJEŽJIMA PLODOVA
}

\section{POPULATION VARIABILITY OF FIELD MAPLE (Acer campestre L.) IN BOSNIA AND HERZEGOVINA ACCORDING TO THE FRUIT MORPHOLOGY}

\author{
Stjepan KVESIĆ'; Dalibor BALLIAN2; Mirzeta MEMIŠEVIĆ HODŽIĆ*
}

\begin{abstract}
SAŽETAK
U radu je prikazana morfološka varijabilnost ploda 25 populacija javora klena (Acer campestre L.) na području Bosne i Hercegovine. Morfometrijsko istraživanje unutar- i među-populacijske varijabilnosti provedeno je na temelju 10 morfoloških značajki ploda, pri čemu su korištene deskriptivne i univarijatne statističke analize. Provedenim istraživanjem najmanje varijabilnim značajkama pokazale su se varijable koje opisuju oblik ploda, sa najmanjom varijabilnošću kod značajke odnos širine i dužine sjemenke. Za razliku od toga, za mjerene značajke ploda utvrđeni su viši koeficijenti varijacije. Najvarijabilnija značajka ploda u javora klena bila je dužina stapčice ploda. Najdivergentnije populacije obuhvaćene ovim istraživanjem bile su populacija Trebinje i populacija Rogatica. Za populaciju Trebinje utvrđene su minimalne srednje vrijednosti za pet od devet analiziranih značajki ploda, a za populaciju Rogatica maksimalne srednje vrijednosti za pet od devet analiziranih značajki. Analizom varijance ustanovljene su statistički značajne razlike između populacija za sve analizirane značajke. Isto tako, istraživanjem je utvrđeno da je unutarpopulacijska varijabilnost veća od međupopulacijske varijabilnosti za većinu istraživanih značajki. Odstupanje od tog pravila pokazuje varijabla F4 (dužina krilca ploda bez sjemenke) gdje komponenta varijance na međupopulacijskoj i unutarpopulacijskoj razini zauzima podjednak udio u ukupnoj varijanci. Provedena istraživanja morfološke varijabilnosti ploda javora klena u Bosni i Hercegovini predstavljaju pionirska istraživanja ove vrste, a dobiveni rezultati, temeljeni na morfometrijskoj analizi morfoloških značajki plodova, mogu poslužiti kao temelj za daljnja istraživanja.
\end{abstract}

KLJUČNE RIJEČI: klen, plod, morfometrijska analiza, morfološka varijabilnost

\section{UVOD}

\section{INTRODUCTION}

Klen je listopadno stablo koje postiže visinu do $15 \mathrm{~m}$, iznimno do $25 \mathrm{~m}$, te promjer debla do $70 \mathrm{~cm}$ (Chybicki i sur. 2014). Nagy i Ducci (2004) navode da postoje primjerci visoki i do $30 \mathrm{~m}$, promjera $90 \mathrm{~cm}$, starosti između 250 i 350 godina. Šilić (1990) ga opisuje kao stablo ili veći grm (na ekstremnim staništima). Jednodomna je vrsta jednospolnih cvjetova, a počinje cvjetati u starosti od oko 25 godina. Plodovi su mu nešto sitniji u odnosu na plodove gorskoga javora i javora mliječa. Sjemenke su plosnate, a krilca zatvaraju kut od oko $180^{\circ}$. Plodovi (kalavci) dozrijevaju u rujnu i listopadu prve godine, a u $1 \mathrm{~kg}$ ide oko 15.600 sjemenki (Herman 1971).

\footnotetext{
1 Dr. sc. Stjepan Kvesić, Šumskogospodarsko društvo / Šumskoprivredno društvo „Šume Središnje Bosne / Srednjobosanske šume“ d.o.o. Donji Vakuf.

2 Prof. dr. sc. Dalibor Ballian, Dr. sc. Mirzeta Memišević Hoď̌ić, Šumarski fakultet u Sarajevu, Zagrebačka 20, 71000 Sarajevo, Bosna i Hercegovina.

*ovo je dio doktorske disertacije kandidata dr. sc. Stjepana Kvesića
} 
Prirodno je rasprostranjen u većem dijelu Europe, izuzev njenih sjevernih dijelova. S obzirom na njegovo malo komercijalno značenje, klen nije podložan različitim šumsko-uzgojnim zahvatima i vrlo često raste u spontano nastalim populacijama. Iz tih razloga klen može poslužiti kao vrijedan model u svrhu istraživanja osjetljivosti populacija na fragmentaciju staništa (Chybicki i sur. 2014). Klen ima iznimno široku ekološku amplitudu (Nagy i Ducci 2004). Raste u područjima s toplijom klimom, međutim otporan je i na zimske uvjete te $\mathrm{u}$ kontinentalnom području tolerira i temperaturne ekstreme (Nagy i Ducci 2004). Iako je najčešći na mezofilnim staništima, posebice u listopadnim hrastovim šumama, rasprostire se od razine mora do 1600 m nadmorske visine (Praciak i sur. 2013). Vrsta je koja ima umjerene potrebe za vodom. Favorizira vapnenačke supstrate, ali uspijeva i na teškim glinenim tlima. Osim toga, raste na tlima kojima je pH niži od 6 i veći od 8. Iznimno je tolerantan na sjenu posebice u prvih deset godina života, a potrebe za svjetlošću su mu veće nakon što počne plodonositi (Nagy i Ducci 2004). Vrlo je tolerantan na orezivanje, što ga čini izuzetno pogodnim za korištenje u živim ogradama (Jones 1945).

Chybicki i sur. (2014) navode da klen ne gradi čiste sastojine, ali je često subdominantna vrsta u mnogim šumskim sastojinama u Europi. U kontinentalnom području raste u mješovitim listopadnim šumama, posebice $s$ vrstama iz rodova Quercus, Tilia, Ulmus i Castanea, dok je vrlo rijedak u šumama četinjača (Jones 1945; FAO 2001). Prema Šiliću (1990), klen raste većinom u listopadnim mješovitim hrastovim šumama, posebno u poplavnim šumama hrasta lužnjaka i poljskoga jasena te u šumama hrasta kitnjaka i običnoga graba, cera i sladuna. Prema istom autoru, klen najbolje uspijeva na rahlim, dubokim i mineralno bogatim tlima s blagim humusom. Na višim nadmorskim visinama, klen ima ograničenu mogućnost zbog dominacije bukve i graba (Nagy i Ducci 2004).

Drenkovski (1979) u svojim istraživanjima ističe veliku morfološku varijabilnost klena na Balkanskom poluotoku koji je ranije opisan i okarakteriziran kao šest različitih vrsta (A. campestre L., A. marsicum Guss., A. austriacum Tratt., A. pseudomarsicum (Pax) Drenk., A. varbossianum (Malý) Sim. i A. pannonicum Drenk.). Herman (1971) navodi da su listovi $5-7 \mathrm{~cm}$ dugački i nešto malo više široki te da su pretežito petero-režnjasti (f. quinquelobum Schwerin = lobatum Pax), a rijetko tro-režnjasti (f. subtrilobum Schwerin). Šilić (2005) opisuje dva varijeteta, od kojih je jedan pustenastih plodova (var. campestre; syn. var. leiocarpum /Opiz/ Wallr.), a drugi golih (var. eriocarpum Wallr.). Navedeno ukazuje na iznimno široku ekološko-morfološku amplitudu populacija koje se obično svrstavaju pod zajedničko ime „klen“ (Jovanović 2000).

Cilj ovog istraživanja je utvrđivanje morfološke varijabilnosti ploda klena na prostoru Bosne i Hercegovine. Utvrđena morfološka varijabilnost populacija klena, može poslužiti u svrhu očuvanja ove vrste i njene raznolikosti, zatim u njenom oplemenjivanju te praćenju njenog reprodukcijskog materijala.

\section{MATERIJAL I METODE MATERIAL AND METHODS}

Materijal za analizu morfološke varijabilnosti populacija klena sakupljen je u 25 prirodnih populacija u Bosni i Her-

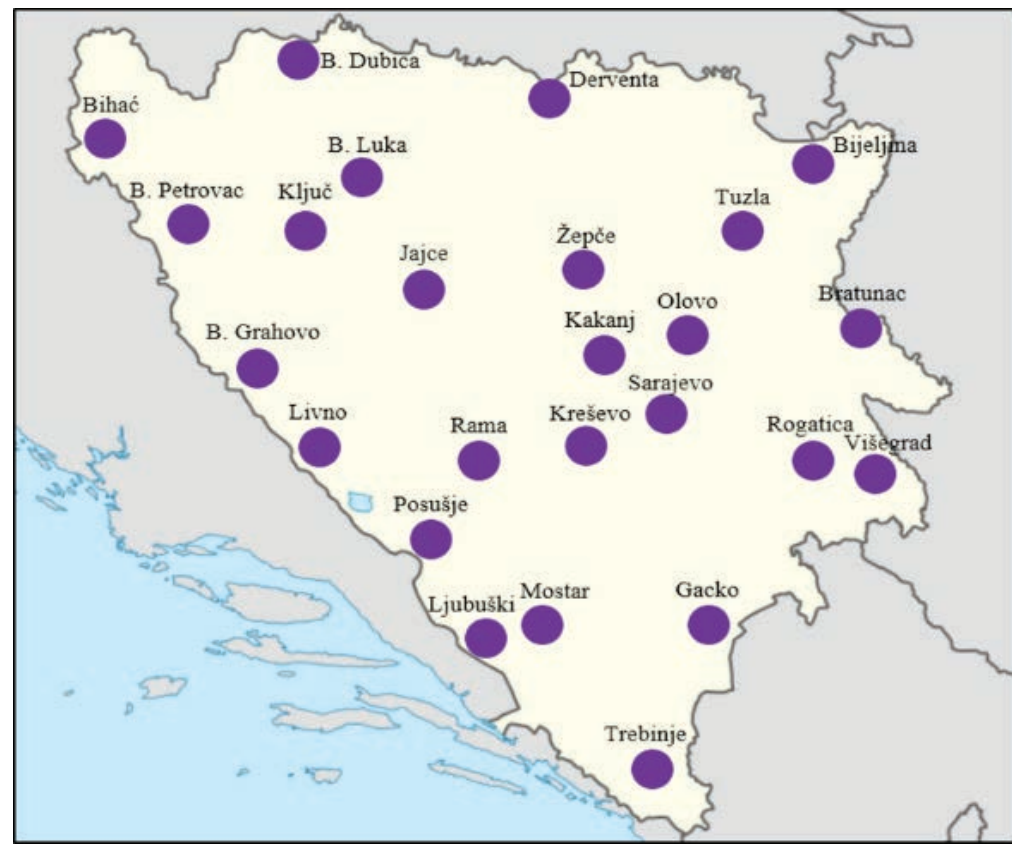

Slika 1. Zemljopisni položaj istraživanih populacija.

Figure 1. Geographic position of researched populations. 
cegovini (slika 1, tablica 1). Svaka od 25 populacija predstavljena je sa po 12 stabala, a svako stablo sa po pet zdravih i neoštećenih plodova. Plodovi su sakupljeni sa stabala na osami ili na rubu šume koja su normalno razvijena, kako bi njihov fenotip bio iskazan u potpunosti bez promjena uvjetovanih uzgojnim mjerama odnosno kako bi pokazivao recentno stanje vrste (Franjić 1996; Kajba 1996; Idžojtić i sur. 2006; Mikić 2007; Ballian i sur. 2010; Zebec i sur. 2010). Ukupno je prikupljeno i morfometrijski obrađeno 1500 plodova. Stabla su bila udaljena najmanje 50 metara jedna od drugih kako bi se izbjegla mogućnost uzorkovanja genetički srodnih jedinki (Zebec i sur. 2010, 2014, 2015; Poljak i sur. 2012, 2014, 2015, 2018). Plodovi za morfometrijsku analizu su sakupljeni u rujnu 2014. godine i izmjereni su digitalnim pomičnim mjerilom. Točnost mjerenja iznosila je $0,1 \mathrm{~mm}$, a za svaki plod mjerene su sljedeće značajke (slika 2 i 3): dužina stapčice $\left(F_{1}\right)$; dužina krilca sa sjemenkom $\left(\mathrm{F}_{2}\right)$; širina krilca $\left(\mathrm{F}_{3}\right)$; dužina krilca bez sjemenke $\left(\mathrm{F}_{4}\right)$; dužina krilca od najšireg dijela krilca $\left(\mathrm{F}_{5}\right)$; dužina sjemenke
$\left(\mathrm{F}_{6}\right)$; širina sjemenke $\left(\mathrm{F}_{7}\right)$; i kut koji međusobno zatvaraju krilca $\left(\mathrm{F}_{8}\right)$. Iz mjerenih značajki izvedeni su sljedeći omjeri: odnos širine krilca i dužine krilcasa sjemenkom $\left(\mathrm{F}_{9}=\mathrm{F}_{3} / \mathrm{F}_{2}\right)$ i odnos širine sjemenke i dužine sjemenke $\left(\mathrm{F}_{10}=\mathrm{F}_{7} / \mathrm{F}_{6}\right)$.

Trend izmjerenih morfoloških značajki opisan je putem deskriptivnih statističkih pokazatelja, pri čijem su izračunu korišteni standardni algoritmi deskriptivne statističke analize (Sokal i Rohlf 1989). Podaci su za sve populacije zajedno prezentirani sljedećim procjeniteljima: broj podataka $(\mathrm{N})$, aritmetička sredina $(\mathrm{M})$, minimalna vrijednost $\left(\mathrm{x}_{\min }\right)$, maksimalna vrijednost $\left(\mathrm{x}_{\max }\right)$, standardna devijacija(SD) i koeficijent varijacije (CV \%). Osim toga, posebno za svaku populaciju izračunata je i: aritmetička sredina $(\mathrm{M})$, standardna devijacija (SD) i koeficijent varijacije (CV \%). Utvrđivanje statistički značajnih razlika između populacija i unutar populacija provedeno je pomoću analize varijance. Analiza je provedena univarijatno za mjerene značajke koje su imale normalnu distribuciju i homogenu varijancu. Za provjeru

Tablica 1. Istraživane populacije.

Table 1. Researched populations.

\begin{tabular}{|c|c|c|c|c|c|c|c|}
\hline $\begin{array}{l}\text { Redni } \\
\text { broj } \\
\text { No. }\end{array}$ & $\begin{array}{l}\text { Populacija } \\
\text { Population }\end{array}$ & $\begin{array}{l}\text { Lokalitet } \\
\text { Locality }\end{array}$ & $\begin{array}{c}\text { Oznaka } \\
\text { populacije } \\
\text { Population ID }\end{array}$ & $\begin{array}{l}\text { Zemljopisna širina } \\
\text { Latitude }\end{array}$ & $\begin{array}{l}\text { Zemljopisna } \\
\text { dužina } \\
\text { Longitude }\end{array}$ & $\begin{array}{c}\text { Srednja nadmorska } \\
\text { visina }(\mathrm{m}) \\
\text { Altitude }\end{array}$ & $\begin{array}{l}\text { Eko-geografsko područje } \\
\text { Eco-geographicregion }\end{array}$ \\
\hline 1. & Posušje & Posuško polje & POS & $43^{\circ} 27^{\prime} 10^{\prime \prime}$ & $17^{\circ} 22^{\prime} 22^{\prime \prime}$ & 710 & Submediteransko-brdsko \\
\hline 2. & Rama & Rumboci & RAM & $43^{\circ} 49^{\prime} 37^{\prime \prime}$ & $17^{\circ} 30^{\prime} 28^{\prime \prime}$ & 625 & Submediteransko-planinsko \\
\hline 3. & Kreševo & Polje & KRE & $43^{\circ} 53^{\prime} 01^{\prime \prime}$ & $18^{\circ} 04^{\prime} 22^{\prime \prime}$ & 570 & Srednje-bosansko \\
\hline 4. & Žepče & Orahovica & ŽEP & $44^{\circ} 25^{\prime} 27^{\prime \prime}$ & $18^{\circ} 03^{\prime} 01^{\prime \prime}$ & 225 & Zavidovićko-teslićko \\
\hline 5. & Jajce & Podmilačje & JAJ & $44^{\circ} 22^{\prime} 33^{\prime \prime}$ & $17^{\circ} 17^{\prime} 36^{\prime \prime}$ & 345 & Srednje-bosansko \\
\hline 6. & Ključ & Čađavica & KLJ & $44^{\circ} 29^{\prime} 08^{\prime \prime}$ & $16^{\circ} 53^{\prime} 34^{\prime \prime}$ & 685 & $\begin{array}{l}\text { Zapadnobosansko krečnjačko- } \\
\text {-dolomitno }\end{array}$ \\
\hline 7. & Banja Luka & Trapisti & BLU & $44^{\circ} 48^{\prime} 25^{\prime \prime}$ & $17^{\circ} 13^{\prime} 36^{\prime \prime}$ & 185 & Sjeverozapadno-bosansko \\
\hline 8. & $\begin{array}{l}\text { Bosansko } \\
\text { Grahovo }\end{array}$ & Bosansko Grahovo & BGR & $44^{\circ} 11^{\prime} 12^{\prime \prime}$ & $16^{\circ} 22^{\prime} 16^{\prime \prime}$ & 845 & Submediteransko-planinsko \\
\hline 9. & Livno & Mali Kablići & LIV & $43^{\circ} 51^{\prime} 19^{\prime \prime}$ & $16^{\circ} 56^{\prime} 31^{\prime \prime}$ & 750 & Submediteransko-brdsko \\
\hline 10. & $\begin{array}{l}\text { Bosanski } \\
\text { Petrovac }\end{array}$ & Vođenica & BPE & $44^{\circ} 37^{\prime} 37^{\prime \prime}$ & $16^{\circ} 14^{\prime} 57^{\prime \prime}$ & 620 & $\begin{array}{l}\text { Zapadnobosansko vapnenasto- } \\
\text {-dolomitno }\end{array}$ \\
\hline 11. & Bihać & Spahići & $\mathrm{BIH}$ & $44^{\circ} 51^{\prime} 29^{\prime \prime}$ & $15^{\circ} 53^{\prime} 17^{\prime \prime}$ & 315 & Cazinske krajine \\
\hline 12. & $\begin{array}{l}\text { Bosanska } \\
\text { Dubica }\end{array}$ & Donji jelovac & BDU & $45^{\circ} 04^{\prime} 44^{\prime \prime}$ & $16^{\circ} 41^{\prime} 25^{\prime \prime}$ & 170 & Sjeverozapadno-bosansko \\
\hline 13. & Ljubuški & Studenci & LJU & $43^{\circ} 10^{\prime} 11^{\prime \prime}$ & $17^{\circ} 37^{\prime} 00^{\prime \prime}$ & 50 & Submediteransko \\
\hline 14. & Mostar & Pijesci & MOS & $43^{\circ} 11^{\prime} 40^{\prime \prime}$ & $17^{\circ} 49^{\prime} 00^{\prime \prime}$ & 225 & Submediteransko \\
\hline 15. & Višegrad & Dobrun & VIŠ & $43^{\circ} 45^{\prime} 17^{\prime \prime}$ & $19^{\circ} 23^{\prime} 17^{\prime \prime}$ & 375 & Gornje-drinsko \\
\hline 16. & Rogatica & Kukavice & ROG & $43^{\circ} 46^{\prime} 55^{\prime \prime}$ & $19^{\circ} 00^{\prime} 28^{\prime \prime}$ & 515 & Gornje-drinsko \\
\hline 17. & Bijeljina & $\begin{array}{l}\text { Dragaljevac } \\
\text { srednji }\end{array}$ & BIJ & $44^{\circ} 49^{\prime} 01^{\prime \prime}$ & $19^{\circ} 01^{\prime} 59^{\prime \prime}$ & 95 & Donje-drinsko \\
\hline 18. & Gacko & Vrba & GAC & $43^{\circ} 13^{\prime} 28^{\prime \prime}$ & $18^{\circ} 34^{\prime} 44^{\prime \prime}$ & 1115 & Submediteransko-planinsko \\
\hline 19. & Trebinje & Dobromani & TRE & $42^{\circ} 47^{\prime} 26^{\prime \prime}$ & $18^{\circ} 09^{\prime} 25^{\prime \prime}$ & 240 & Submediteransko \\
\hline 20. & Derventa & Lužani & DER & $45^{\circ} 01^{\prime} 05^{\prime \prime}$ & $17^{\circ} 59^{\prime} 29^{\prime \prime}$ & 115 & Sjeverno-bosansko \\
\hline 21. & Kakanj & Donja papratnica & KAK & $44^{\circ} 04^{\prime} 42^{\prime \prime}$ & $18^{\circ} 06^{\prime} 06^{\prime \prime}$ & 450 & Srednje-bosansko \\
\hline 22. & Tuzla & Donje dubrave & TUZ & $44^{\circ} 29^{\prime} 39^{\prime \prime}$ & $18^{\circ} 40^{\prime} 50^{\prime \prime}$ & 245 & Sjeverno-bosansko \\
\hline 23. & Olovo & Boganovići & OLO & $44^{\circ} 08^{\prime} 18^{\prime \prime}$ & $18^{\circ} 33^{\prime} 11^{\prime \prime}$ & 510 & Zavidovićko-teslićko \\
\hline 24. & Bratunac & Konjevići & BRA & $44^{\circ} 14^{\prime} 48^{\prime \prime}$ & $19^{\circ} 06^{\prime} 38^{\prime \prime}$ & 220 & Donje-drinsko \\
\hline 25. & Sarajevo & Tihovići & SAR & $43^{\circ} 55^{\prime} 13^{\prime \prime}$ & $18^{\circ} 22^{\prime} 48^{\prime \prime}$ & 690 & Srednje-bosansko \\
\hline
\end{tabular}




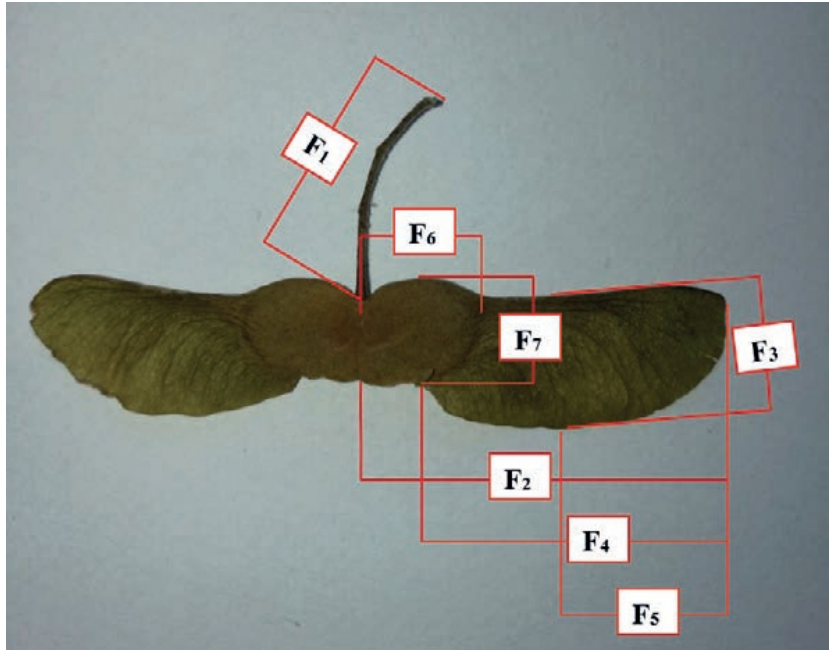

Slika 2. Mjerene značajke ploda $\left(F_{1}-F_{7}\right)$.

Figure 2. Measured fruit traits $\left(F_{1}-F_{7}\right)$.

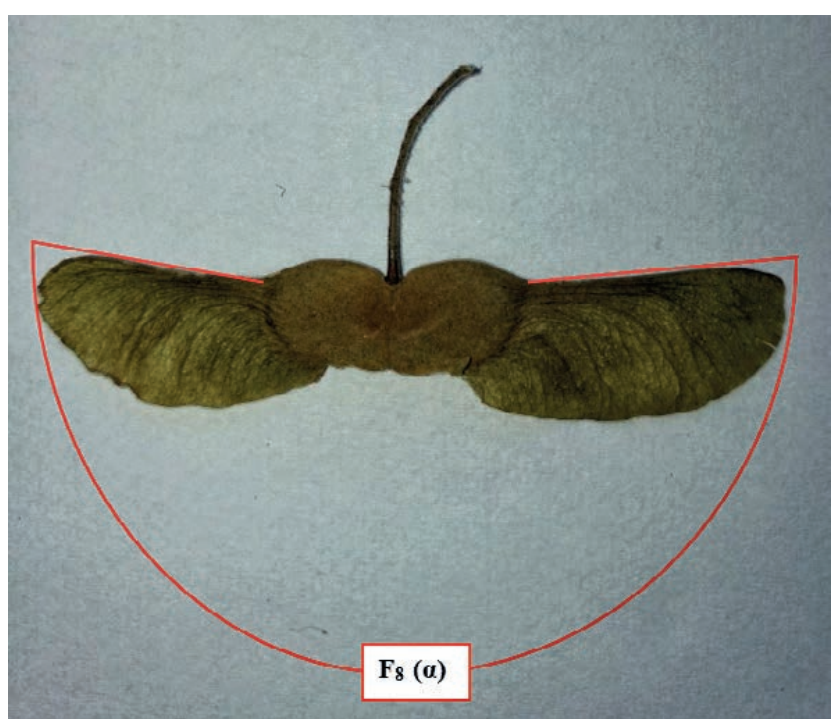

Slika 3. Mjerena značajka ploda $\left(F_{8}\right)$.

Figure 3. Measured fruit traits $\left(\mathrm{F}_{8}\right)$. normalnosti raspodjele analiziranih podataka korišten je Kolmogorov-Smirnov test. $U$ analizu su uključene sve istraživane značajke osim širine krilca $\left(\mathrm{F}_{3}\right)$ za koju je utvrđeno da nema normalnu distribuciju i homogenu varijancu. Analizirani faktori varijabilnosti bili su populacija i stablo, na način da je faktor „stablo“ ugniježđen unutar faktora „populacija“. Nadalje, kako bi se utvrdilo koje se točno populacije međusobno signifikantno razlikuju, provedeno je i dodatno testiranje Tukeyevim multiplim testovima (HSD) za sve parove populacija. Da bi se dobio uvid u zastupljenost pojedinih istraživanih izvora varijabilnosti u ukupnoj varijanci (između populacija, između stabala unutar populacije, unutar stabla) korištena je REML metoda (Restricted Maximum Likelihood Method). Navedene statističke analize izvršene su u statističkom programu SPSS 20.0 (IBM Corp. 2011).

\section{REZULTATI RESULTS}

Najveći stupanj varijabilnosti imala je dužina stapčice ploda $\left(F_{1}\right), C V=32,31 \%$. Najstabilnija značajka ploda, odnosno značajka s najmanjim koeficijentom varijacije, utvrđena je za odnos širine sjemenke i dužine sjemenke $\left(\mathrm{F}_{10}\right), \mathrm{CV}=8,13$ $\%$. Navedene vrijednosti, kao i ostali rezultati deskriptivne statističke analize za sve populacije zajedno, prikazani su u tablici 2, a za svaku populaciju posebno u tablici 3 .

Dužina stapčice ploda $\left(F_{1}\right)$ kretala se u rasponu od 4,20 do $30,30 \mathrm{~mm}$. Srednja vrijednost ove značajke, izračunata za sve populacije zajedno, iznosila je 12,63 mm. Najmanja srednja vrijednost dužine stapčice ploda karakteristična je za populaciju Gacko, a najveća za populaciju Derventa. Populacija Kreševo imala je najveći koeficijent varijacije za navedenu značajku, CV 35,72 \%. Najmanja vrijednost koeficijenta varijacije od 19,06 \% bila je karakteristična za populaciju Ključ.

Tablica 2. Parametri deskriptivne statistike za mjerene morfološke značajke za sve populacije zajedno.

Table 2. Descriptive statistical parameters for measured morphological traits for all populations together.

\begin{tabular}{|c|c|c|c|c|c|c|}
\hline $\begin{array}{c}\text { Značajka } \\
\text { Trait }\end{array}$ & $\mathrm{N}$ & M & $\mathrm{x}_{\min }$ & $\mathrm{x}_{\max }$ & SD & $\mathrm{CV}(\%)$ \\
\hline$F_{1}(\mathrm{~mm})$ & 1500 & 12,63 & 4,20 & 30,30 & 4,08 & 32,31 \\
\hline $\mathrm{F}_{2}(\mathrm{~mm})$ & 3000 & 28,35 & 14,50 & 43,50 & 4,09 & 14,42 \\
\hline $\mathrm{F}_{4}(\mathrm{~mm})$ & 3000 & 27,10 & 11,10 & 43,50 & 4,57 & 16,86 \\
\hline $\mathrm{F}_{5}(\mathrm{~mm})$ & 3000 & 11,11 & 4,50 & 21,50 & 2,32 & 20,90 \\
\hline $\mathrm{F}_{6}(\mathrm{~mm})$ & 3000 & 8,56 & 5,60 & 11,90 & 0,99 & 11,54 \\
\hline $\mathrm{F}_{7}(\mathrm{~mm})$ & 3000 & 8,14 & 5,20 & 11,80 & 0,95 & 11,65 \\
\hline $\mathrm{F}_{8}\left({ }^{\circ}\right)$ & 1500 & 182,87 & 120,00 & 247,00 & 21,26 & 11,63 \\
\hline $\mathrm{F}_{9}$ & 3000 & 0,33 & 0,20 & 0,50 & 0,04 & 12,92 \\
\hline $\mathrm{F}_{10}$ & 3000 & 0,95 & 0,70 & 1,23 & 0,08 & 8,13 \\
\hline
\end{tabular}




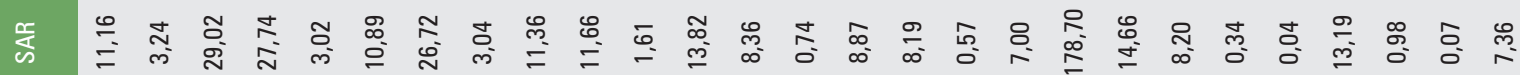

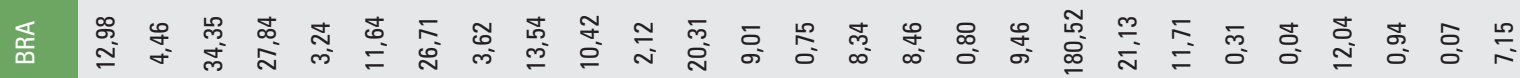

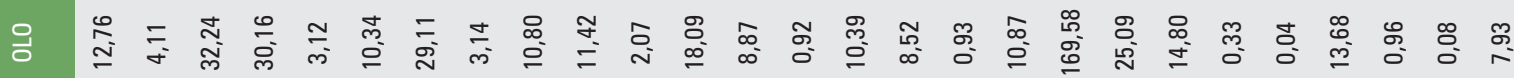

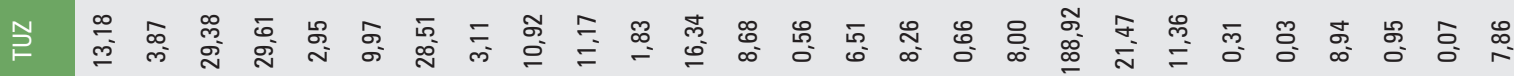

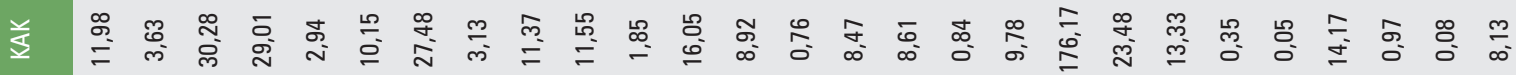

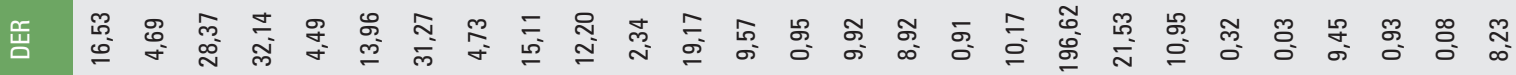

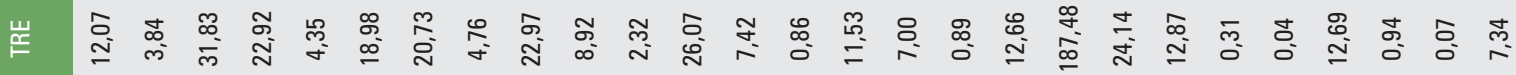

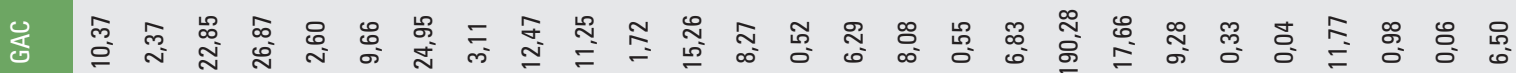

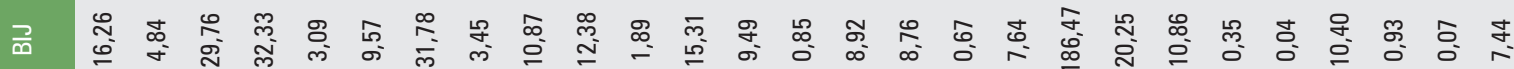

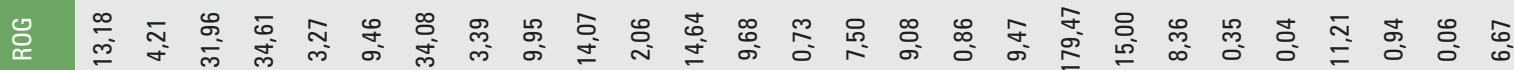

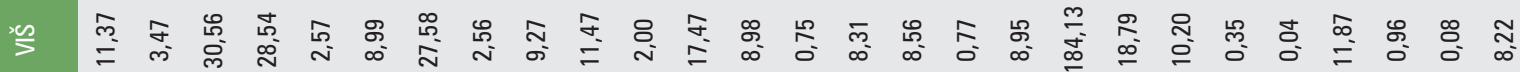

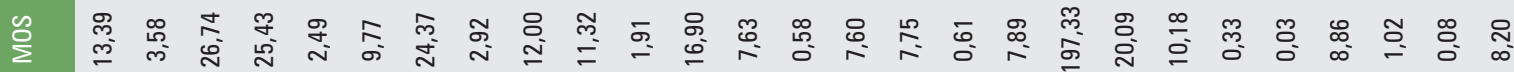

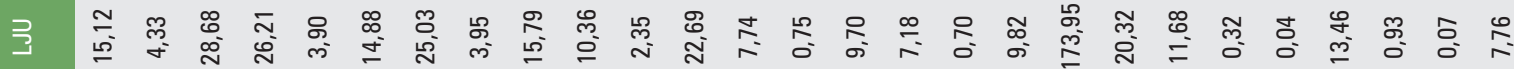

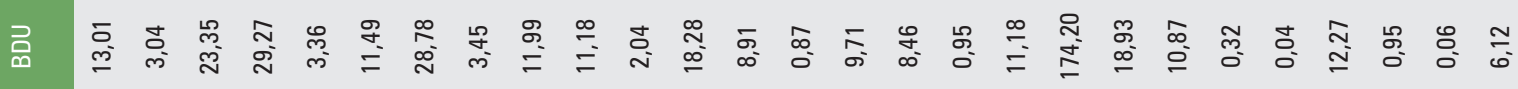

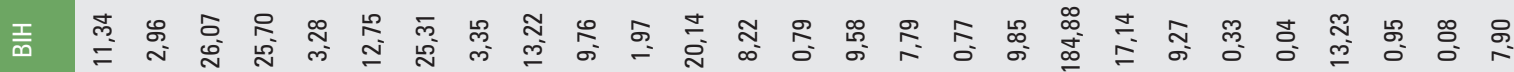

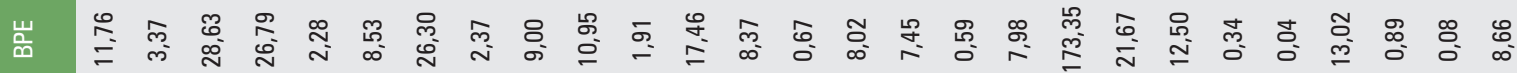

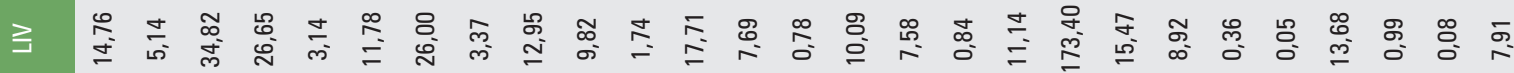

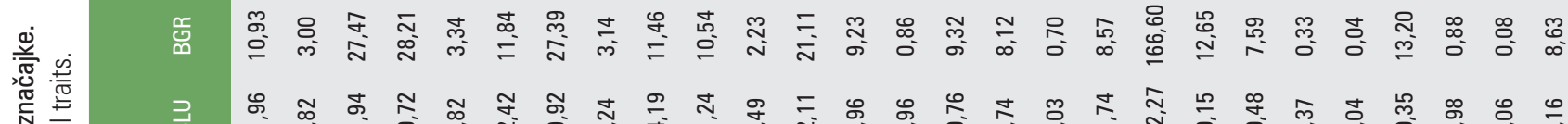

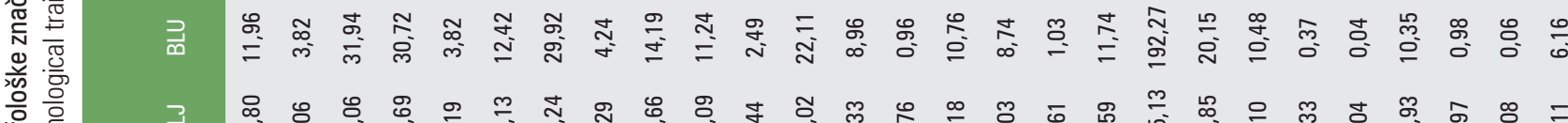

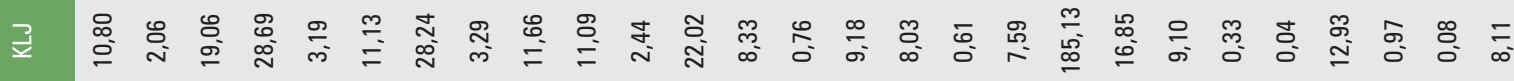

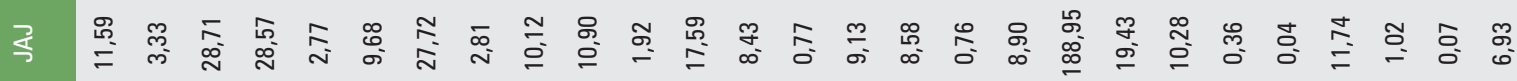

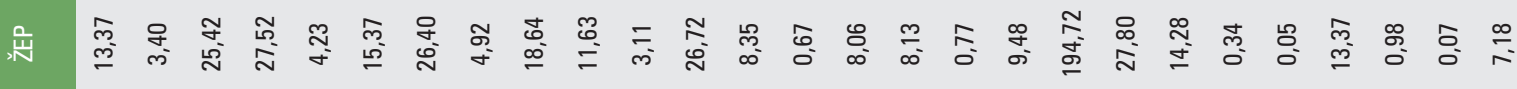

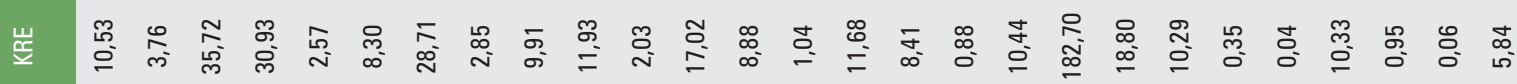

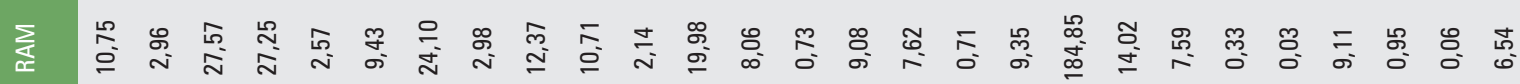

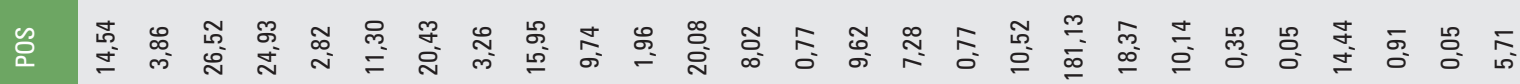


Za značajku dužina krilca sa sjemenkom $\left(\mathrm{F}_{2}\right)$ utvrđen je koeficijent varijabilnosti od $14,42 \%$. Pojedinačne vrijednosti kretale su se u rasponu od 14,50 do $43,50 \mathrm{~mm}$, a srednja vrijednost ove značajke iznosila je $28,35 \mathrm{~mm}$. Najmanja aritmetička sredina zabilježena je u populacije Trebinje i iznosila je 22,92 mm, dok je najveća zabilježena u populacije Rogatica i iznosila je 34,61 mm. Najveća varijabilnost karakterizirala je populaciju Trebinje $(\mathrm{CV}=18,98 \%)$, a najmanja populaciju Kreševo (CV = 8,30 \%).

Koeficijent varijacije od 16,86 \% bio je svojstven dužini krilca ploda bez sjemenke $\left(\mathrm{F}_{4}\right)$. Navedena značajka varirala je od 11,10 do 43,50 mm. Srednja vrijednost ove značajke iznosila je 27,10 mm. Prosječno najmanje vrijednosti za navedenu značajku zabilježene su u populaciji Posušje $(20,43$ $\mathrm{mm})$, a prosječno najveće u populaciji Rogatica $(34,08$ $\mathrm{mm}$ ). Populacija Trebinje imala je najveći stupanj varijabilnosti $(\mathrm{CV}=22,97 \%)$, a populacija Bosanski Petrovac najmanji $(\mathrm{CV}=9,00 \%)$.

Za značajku dužina krilca od najšireg dijela krilca $\left(\mathrm{F}_{5}\right) \mathrm{utvr-}$ đen je koeficijent varijacije od 20,90 \%. Dužina krilca od najšireg dijela krilca varirala je od 4,50 do 21,50 mm. Srednja vrijednost ove značajke iznosila je $11,11 \mathrm{~mm}$. Najniža srednja vrijednost bila je karakteristična za populaciju Trebinje i iznosila je $8,92 \mathrm{~mm}$, dok je najveća srednja vrijednost bila karakteristična za populaciju Rogatica i iznosila je 14,07 $\mathrm{mm}$. Najveći stupanj varijabilnosti $(\mathrm{CV}=26,72 \%)$ bio je svojstven populaciji Žepče, a najmanji populaciji Sarajevo $(\mathrm{CV}=13,82 \%)$.
Dužina sjemenke $\left(\mathrm{F}_{6}\right)$ kretala se u rasponu od 5,60 do 11,90 $\mathrm{mm}$ s prosječnim koeficijentom varijacije $11,54 \%$. Srednja vrijednost dužine sjemenke iznosila je $8,56 \mathrm{~mm}$. Najmanja srednja vrijednost dužine sjemenke utvrđena je za populaciju Trebinje 7,42 mm, a najveća za populaciju Rogatica 9,68 $\mathrm{mm}$. Najvarijabilnija populacija s obzirom na navedenu značajku bila je populacija Kreševo (CV $=11,68 \%)$, a najmanje varijabilna populacija Gacko $(\mathrm{CV}=6,29 \%)$.

Širina sjemenke $\left(\mathrm{F}_{7}\right)$ za 25 istraživanih populacija kretala se je u rasponu od 5,20 do $11,80 \mathrm{~mm}$. Srednja vrijednost širine sjemenke iznosila je $8,14 \mathrm{~mm}$ s koeficijentom varijacije od 11,65\%. Najmanja srednja vrijednost širine sjemenke utvrđena je u populaciji Trebinje i iznosila je 7,00 $\mathrm{mm}$, a najveća u populaciji Rogatica i iznosila je $9,08 \mathrm{~mm}$. Najveću varijabilnost, kada je u pitanju širina sjemenke, imala je populacija Trebinje u koje je koeficijent varijacije iznosio 12,66 \%, a najmanju varijabilnost, kao i u značajke dužina sjemenke $\left(\mathrm{F}_{6}\right)$, imala je populacija Gacko u koje je koeficijent varijacije iznosio od 6,83\%.

Vrijednost koeficijenta varijacije za kut koji međusobno zatvaraju krilca $\left(\mathrm{F}_{8}\right)$ iznosila je 11,63\%. Navedeni kut kretao se u rasponu od $120^{\circ}$ do $247^{\circ}$. Srednja vrijednost kuta iznosila je $182,87^{\circ}$. Najmanja srednja vrijednost bila je karakteristična za populaciju Bosansko Grahovo i iznosila je $166,60^{\circ}$, a najveća za populaciju Mostar i iznosila je 197,33․ Populacija Olovo je imala najveću varijabilnost $(\mathrm{CV}=14,80 \%)$, a populacija Bosansko Grahovo najmanju ( $\mathrm{CV}=7,59 \%)$.

Tablica 4. Rezultati univarijatne analize varijance (ANOVA).

Table 4. Results of univariate analysis of variance (ANOVA).

\begin{tabular}{|c|c|c|c|c|c|c|}
\hline $\begin{array}{c}\text { Značajka } \\
\text { Trait }\end{array}$ & $\begin{array}{l}\text { Izvor varijabilnosti } \\
\text { Source of Variation }\end{array}$ & $\begin{array}{l}\text { Suma kvadrata } \\
\text { Sum of Squares }\end{array}$ & $\begin{array}{l}\text { Broj stupnjeva } \\
\text { slobode } \\
\text { Degree of freedom }\end{array}$ & $\begin{array}{l}\text { Sredina kvadrata } \\
\text { MeanSquare }\end{array}$ & $\begin{array}{l}\text { F vrijednost } \\
\text { F Value }\end{array}$ & $\begin{array}{l}\text { Značajnost } \\
\text { Significance }\end{array}$ \\
\hline \multirow{2}{*}{$F_{1}$} & Populacija & 86,93 & 24 & 3,62 & 4,70 & $p<0,0001$ \\
\hline & Stablo/Populacija & 212,07 & 275 & 0,77 & & \\
\hline \multirow{2}{*}{$\mathrm{F}_{2}$} & Populacija & 143,20 & 24 & 5,97 & 10,53 & $p<0,0001$ \\
\hline & Stablo/Populacija & 155,80 & 275 & 0,57 & & \\
\hline \multirow{2}{*}{$\mathrm{F}_{4}$} & Populacija & 160,98 & 24 & 6,71 & 13,37 & $p<0,0001$ \\
\hline & Stablo/Populacija & 138,02 & 275 & 0,50 & & \\
\hline \multirow{2}{*}{$\mathrm{F}_{5}$} & Populacija & 94,10 & 24 & 3,92 & 5,26 & $p<0,0001$ \\
\hline & Stablo/Populacija & 204,90 & 275 & 0,75 & & \\
\hline \multirow{2}{*}{$F_{6}$} & Populacija & 143,47 & 24 & 5,98 & 10,57 & $p<0,0001$ \\
\hline & Stablo/Populacija & 155,53 & 275 & 0,57 & & \\
\hline \multirow{2}{*}{$\mathrm{F}_{7}$} & Populacija & 127,07 & 24 & 5,29 & 8,47 & $\mathrm{p}<0,0001$ \\
\hline & Stablo/Populacija & 171,93 & 275 & 0,63 & & \\
\hline \multirow{2}{*}{$F_{8}$} & Populacija & 55,46 & 24 & 2,31 & 2,61 & $p<0,0001$ \\
\hline & Stablo/Populacija & 243,54 & 275 & 0,89 & & \\
\hline \multirow{2}{*}{$F_{9}$} & Populacija & 52,75 & 24 & 2,20 & 2,45 & $p<0,0001$ \\
\hline & Stablo/Populacija & 246,25 & 275 & 0,90 & & \\
\hline \multirow{2}{*}{$F_{10}$} & Populacija & 72,22 & 24 & 3,01 & 3,65 & $p<0,0001$ \\
\hline & Stablo/Populacija & 226,78 & 275 & 0,82 & & \\
\hline
\end{tabular}


Tablica 5. Komponente varijance.

Table 5. Variance components.

\begin{tabular}{ccccc} 
& \multicolumn{5}{c}{ Efekt (\%) } \\
ZNAČAJKA & Populacija & Stablo / populacija & Ostatak & UKUPNO \\
& 12,97 & 34,87 & 52,16 & 100,00 \\
$\mathrm{~F}_{1}$ & 35,27 & 44,83 & 19,90 & 100,00 \\
$\mathrm{~F}_{2}$ & 41,12 & 40,26 & 18,62 & 100,00 \\
$\mathrm{~F}_{4}$ & 17,04 & 47,42 & 35,54 & 100,00 \\
$\mathrm{~F}_{5}$ & 34,42 & 44,32 & 21,26 & 100,00 \\
$\mathrm{~F}_{6}$ & 30,11 & 49,20 & 20,69 & 100,00 \\
$\mathrm{~F}_{7}$ & 9,13 & 65,93 & 24,94 & 100,00 \\
$\mathrm{~F}_{8}$ & 7,74 & 69,03 & 23,23 & 100,00 \\
$\mathrm{~F}_{9}$ & 14,62 & 62,53 & 22,84 & 100,00 \\
$\mathrm{~F}_{10}$ & & & & \\
\hline
\end{tabular}

Za odnos širine krilca ploda i dužine krilca ploda s orašicom $\left(\mathrm{F}_{9}\right)$ bio je svojstven koeficijent varijacije od 12,92\%. Vrijednost istraživanog svojstva varirala je od 0,20 do 0,50 . Srednja vrijednost ovoga svojstva iznosila je 0,33 $\pm 0,001$. Najniža srednja vrijednost bila je karakteristična za populaciju Trebinje i iznosila je 0,31 $\pm 0,004$, dok je najveća srednja vrijednost bila karakteristična za populaciju B. Luka i iznosila je $0,37 \pm 0,003$. Najveći stupanj varijabilnosti sa vrijednošću koeficijenta varijacije od 14,44\% svojstven je populaciji Posušje, dok je najmanji karakterističan za populaciju Mostar s vrijednošću koeficijenta od 8,86\%.

Za odnos širine i dužine sjemenke $\left(\mathrm{F}_{10}\right)$ utvrđena je najmanja varijabilnost od svih istraživanih značajki ploda. Navedeni omjer kretao se u rasponu od 0,70 do 1,23, a srednja vrijednost ove značajke iznosila je 0,95 . Najmanji prosječni odnos širine i dužine sjemenke imala je populacija Bosansko Grahovo 0,88, a najveći populacija Mostar 1,02. Najvarijabilnija populacija s obzirom na ovu značajku bila je Bosanski Petrovac (CV $=8,66 \%)$, a najmanje varijabilna populacija Posušje $(\mathrm{CV}=5,71 \%)$.

Analizom varijance utvrđeno je da se istraživane populacije statistički značajno razlikuju za svih devet analiziranih značajki ploda, što je vidljivo iz tablice 4 . U svrhu postizanja uvjeta normalnosti pri analizi varijance korišteni su prosjeci jedinki, a ne podaci za pojedinačne plodove.

Višestrukim testiranjem utvrđeno je da je dužina krilca ploda bez sjemenke $\left(\mathrm{F}_{4}\right)$, značajka koja u najvećoj mjeri doprinosi razlikovanju populacija javora klena. Za navedenu značajku utvrđeno je da su se populacije, na razini značajnosti 0,05 , međusobno statistički značajno razlikovale u 30,33 \% slučajeva višestrukih usporedbi. Nakon ove značajke, najveći doprinos u razlikovanju populacija javora klena kada je u pitanju plod, imala je značajka dužina sje- menke $\left(\mathrm{F}_{6}\right)$ pomoću koje su se populacije statistički značajno razlikovale u $26,67 \%$ slučajeva višestrukih usporedbi. Zatim slijedi značajka dužina krilca ploda sa sjemenkom $\left(\mathrm{F}_{2}\right)$ u kojega je ovaj postotak iznosio 25,00 te značajka širina sjemenke $\left(\mathrm{F}_{7}\right) \mathrm{u}$ kojega su se populacije statistički značajno razlikovale u 21,00 \% slučajeva. Populacije javora klena u najmanjoj mjeri razlikovale su se za značajku odnos širine krilca ploda i dužine krilca ploda sa sjemenkom $\left(\mathrm{F}_{9}\right)$. Osim ove značajke, relativno mali doprinos u razlikovanju populacija imale su značajke: kut koji međusobno zatvaraju krilca $\left(\mathrm{F}_{8}\right)$; odnos širine sjemenke i dužine sjemenke $\left(\mathrm{F}_{10}\right)$; dužina stapčice ploda $\left(\mathrm{F}_{1}\right)$; i dužina krilca ploda od najšireg dijela krilca $\left(\mathrm{F}_{5}\right)$.

Za sve analizirane značajke ploda zajedno, utvrđeno je da se populacija Trebinje najviše razlikuje u odnosu na ostale istraživane populacije. Naime, ova populacija se, na razini značajnosti 0,05 , od ostalih populacija međusobno statistički značajno razlikovala u 39,35 \% slučajeva višestrukih usporedbi. Zatim slijedi populacija Rogatica, koja se od ostalih populacija međusobno statistički značajno razlikovala u 36,57 \% slučajeva. Kada je riječ o razlikama u analiziranim značajkama ploda, osim ovih dviju populacija u nešto većoj mjeri bile su divergentne populacije: Derventa, Bijeljina i Posušje. S druge strane, populacija koja se u pogledu analiziranih značajki ploda najmanje razlikovala u odnosu na ostale istraživane populacije, bila je populacija Ključ. Populacija Ključ se od ostalih istraživanih populacija razlikovala u svega $6,94 \%$ slučajeva višestrukih usporedbi. Nakon ove populacije najmanju divergentnost pokazale su populacije: Tuzla, Višegrad i Žepče u kojih je ovaj postotak iznosio 7,41\% zatim, populacije: Bosanska Dubica, Kakanj, Gacko, Sarajevo, Bratunac, Olovo i Jajce, koje su se razlikovale u manje od 10,00 \% slučajeva višestrukih usporedbi. Populacije: Bihać, Kreševo, Rama, Bosansko Grahovo, Bosanski Petrovac, Banja Luka, Livno, Ljubuški i Mostar, su se statistički značajno razlikovale između 10,00 i 20,00 \% slučajeva višestrukih usporedbi.

REML metodom (Restricted Maximum Likelihood Method) dobiven je uvid u zastupljenost pojedinih istraživanih izvora varijabilnosti u ukupnoj varijanci (između populacija, između stabala unutar populacije, ostatak). Provedenom analizom utvrđena je veća unutarpopulacijska nego međupopulacijska varijabilnost. Odstupanje od toga pravila pokazuje značajka dužina krilca ploda bez sjemenke $\left(\mathrm{F}_{4}\right)$ kod koje međupopulacijska i unutarpopulacijska varijabilnost zauzimaju podjednak udio u ukupnoj varijanci.

\section{RASPRAVA I ZAKLJUČCI DISCUSSION AND CONCLUSIONS}

Zanimljiva je činjenica da morfološka istraživanja klena nisu bila predmetom brojnih i opsežnih istraživanja na prostoru Europe. Razlozi ponajprije leže u malom komercijal- 
nom značaju ove vrste, iako predstavlja značajan ekološki element različitih ekosustava unutar svoje prirodne rasprostranjenosti, kao i agrikulturnih pejzaža. Primarni fokus istraživača ove vrste (Drenkovski 1979) bila je unutarvrsna taksonomija kompleksa Acer campestre sensu latissimo.

Iako su u današnje vrijeme molekularne metode dominantne u populacijskim istraživanjima (Ballian i Tröber 2017; Zebec i sur. 2016; Poljak i sur. 2017), morfometrijske metode još uvijek imaju značajnu ulogu u razjašnjavanju obrazaca unutar- i među-populacijske varijabilnosti (Ballian i sur. 2010, 2014; Brus i sur. 2011; Jarni i sur. 2011; Galvan i sur. 2012; Jasińska i sur. 2013; Poljak i sur. 2012, 2014, 2015, 2018; Paridari i sur. 2013; Zebec i sur. 2010, 2014, 2015; Popović i Kerkez 2016). Unatoč brojnim istraživanjima u prošlosti (Pax 1885; Malý 1906; Hayek 1927; Plavšić 1941; Fukarek 1953; Drenkovski 1979), taksonomija klena (Acer campestre s.l.) još uvijek nije u potpunosti razjašnjena zbog izrazite lokalne i regionalne varijabilnosti ove vrste. Sama činjenica o prisutnoj i neriješenoj taksonomskoj kompleksnosti posredno ukazuje na veliku morfološku varijabilnost unutar vrste. Provedena detaljna istraživanja morfološke varijabilnosti klena u Bosni i Hercegovini predstavljaju pionirska istraživanja ove vrste. Istraživanjima je potvrđena velika morfološka varijabilnost istraživane vrste, kao i značajna izdiferenciranost i strukturiranost populacija na malom prostoru unutar Bosne i Hercegovine, u usporedbi s ukupnom prirodnom rasprostranjenošću ove vrste.

Najvarijabilnija značajka ploda u javora klena bila je dužina stapčice ploda $\left(\mathrm{F}_{1}\right)$. Nasuprot tomu, najmanje varijabilnom značajkom pokazao se odnos širine i dužine sjemenke $\left(\mathrm{F}_{10}\right)$. I u drugih vrsta javora utvrđeni su isti obrasci (Tripić 2011), kao i u nekih drugih vrsta drveća (Poljak 2014). Najdivergentnije populacije obuhvaćene ovim istraživanjem bile su populacija Trebinje i populacija Rogatica. Za populaciju Trebinje utvrđene su minimalne srednje vrijednosti za pet od devet analiziranih značajki ploda, a za populaciju Rogatica maksimalne srednje vrijednosti za pet od devet analiziranih značajki.

Analizom varijance ustanovljene su statistički značajne razlike između populacija za svih devet analiziranih značajki ploda. Isto tako, istraživanjem je utvrđeno da je unutarpopulacijska varijabilnost veća od međupopulacijske varijabilnosti za većinu istraživanih značajki. Odstupanje od tog pravila pokazuje varijabla $\mathrm{F}_{4}$ (dužina krilca ploda bez sjemenke) gdje komponenta varijance na međupopulacijskoj i unutarpopulacijskoj razini zauzima podjednak udio u ukupnoj varijanci. Ovakvi rezultati su u skladu s rezultatima ostalih autora koji istražuju morfološku varijabilnost populacija drvenastih vrsta (Ballian i sur. 2010, 2014; Bolvanský i Užik 2005; Brus i sur. 2011; Jarni i sur. 2011; Poljak 2014; Poljak i sur. 2012, 2014, 2015, 2018; Popović i Kerkez 2016; Zebec i sur. 2010, 2014, 2015).
Općenito uzevši, uzorkovane populacije klena u Bosni i Hercegovini odlikovale su se visokim stupnjem varijabilnosti ploda, pri čemu su izvedene značajke bile manje varijabilne od mjernih, ukazavši tako na nižu stopu variranja oblika od dimenzija ploda.

Kako bi se donijeli kritičniji zaključci o varijabilnosti populacija javora klena na području Bosne i Hercegovine i ostaloga dijela njegove prirodne rasprostranjenosti, potrebno je istraživanja proširiti i na morfometrijska istraživanja vegetativnih biljnih organa, kao i na molekularno-biološke metode istraživanja. Dobiveni rezultati, temeljeni na morfometrijskoj analizi morfoloških značajki plodova, mogu poslužiti kao temelj za nastavak istraživanja s ciljem utvrđivanja interakcije ekoloških, zemljopisnih i morfoloških značajki.

\section{LITERATURA}

\section{REFERENCES}

- Ballian D., A. Hajrudinović, J. Franjić, F. Bogunić 2014: Morfološka varijabilnost lista makedonskoga hrasta (Quercustrojana Webb.) u Bosni i Hercegovini i Crnoj Gori. Šumarski list, 138(3-4): 135-144. Zagreb.

- Ballian D., M. Memišević, F. Bogunić, N. Bašić, M. Marković, D. Kajba 2010: Morfološka varijabilnost hrasta lužnjaka (Quercusrobur L.) na području Hrvatske i zapadnog Balkana. Šumarski list, 134(7-8): 371-386. Zagreb.

- Ballian, D., U. Tröber, 2017: Genetska karakterizacija europske crne topole (Populus nigra L.) u Bosni i Hercegovini. Šumarski list, 141 (7-8): 351-362. Zagreb.

- Bolvanský M., M. Užik 2005: Morphometric variation and differentiation of European Chestnut (Castanea sativa) in Slovakia. Biologia, 60: 423-429. Bratislava.

- Brown J. D. 1997: Statistics Corner: Questions and answers about language testing statistics: Skewness and kurtosis. Shiken: JALT Testing\&Evaluation SIG Newsletter, 1(1): 16-18.

- Brus R., D. Ballian, F. Bogunić, M. Bobinac, M. Idžojtić 2011: Leaflet morphometric variation of service tree (Sorbus domestica L.) in the Balkan peninsula. Plant Biosystems, 145: 278285.

- Chybicki I.J., B Waldon-Rudzionek, K. Meyza 2014: Population at the edge: increased divergence but not in breeding towards northern range limit in Acer campestre. Tree Genetics and Genomes, 10: 1739-1753.

- Drenkovski R. 1979: Taksonomska obrada Acer campestre-Acer marsicum- kompleksa u Jugoslaviji. Doktorska disertacija.str. 116-139. Skopje-Beograd

- Food and Agriculture Organization of the United Nations, 2001: Global Ecological Zoning for the Global Forest Resources Assessment 2000. Forestry Department, Rome, Italy.

- Franjić J. 1996: Morfometrijska analiza varijabilnosti lista posavskih i podravskih populacija hrasta lužnjaka (Quercusrobur L., Fagaceae) u Hrvatskoj, Glasnik za šumske pokuse, 33: 153-214. Zagreb.

- Fukarek P. 1953: Javori Bosne i Hercegovine u radovima Karla Malý-a. Godišnjak Biološkog Instituta u Sarajevu. God. V., Sv. 1-2. Sarajevo. 
- Galvan J.V., J.J.J. Novo, A.G. Cabrera, D. Ariza, J. Garcia-Olmo, R.M.N. Cerrillo 2012: Population variability based on the morphometry and chemical composition of the acorn in Holm oak (Quercus ilex subsp. ballota [Desf] Samp.). European Journal ofForest Research, 131: 893-904.

- Hayek A. 1927: Prodromus Florae peninsulae Balcanicae. Bd. I. Beihefte zu Fedde Repert. Spec. Novar. Bd. XXX/1. Str. 601-607. Berlin - Dahlen

- Herman, J., 1971: Šumarska dendrologija, Stanbiro, 470 str., Zagreb.

- IBM Corp. Released 2011. IBM SPSS Statistics for Windows, Version 20.0. Armonk, New York.

- Idžojtić M., M. Zebec, D. Drvodelić 2006: Varijabilnost populacija brekinje u kontinentalnom dijelu Hrvatske prema morfološkim obilježjima lišća i plodova. Glasnik za šumske pokuse, Posebno izdanje, 5: 305-314. Zagreb.

- Jarni K., M. Westergren, H. Kraigher, R. Brus 2011: Morphological variabilityof Fraxinus angustifolia Vahl in the northwestern Balkans. Acta Societatis Botanicorum Poloniae, 80: 245-252.

- Jasińska A.K., K. Boratyńska, K. Sobierajska, A. Romo, T. Ok, M.B.D. Kharat, A. Boratyński 2013: Relationships among Cedrus libani, C. brevifolia and C. atlantica as revealed by the morphological and anatomical needle characters. Plant Systematics and Evolution, 299: 35-48.

- Jones E.W. 1945: Biological Flora of the British Isles: Acer pseudoplatanus L. Journal of Ecology, 32: 220-237.

- Jovanović B. 2000: Dendrologija. Univerzitetski udžbenik. Str. 360. Beograd

- Kajba D. 1996: Međupopulacijska i unutarpopulacijska varijabilnost breze (Betulapendula Roth.) u dijelu prirodne rasprostranjenosti u Republici Hrvatskoj. Glasnik za šumske pokuse, 33: 53-108.

- Malý K. 1906: Acer campestre L. var. varbossanium Malý u Dörfler. Herbarium Normale Schedae ad Cent. XLVII. Wien, 4617: 190.

- Mikić T. 2007: Analiza morfoloških parametara lista divlje trešnje (Prunus avium L.) u Bosni i Hercegovini. Disertacija, Šumarski fakultet u Banja Luci.

- Nagy L., F. Ducci 2004: EUFORGEN Technical Guidelines for geneticconservation and use for field maple (Acer campestre). International Plant Genetic Resources Institute, Rome, Italy. Str. 1-6. Rome.

- Paridari I. C., S.G. Jalali, A. Sonboli, M. Zarafshar, F. Bruschi 2013: Leaf macro- and micro-morphologicalaltitudinal variability of Carpinus betulus in the Hyrcanian forest (Iran). Journal of Forestry Research, 24: 301-307.

- Pax F. 1885: Monographie der Gattung Acer. Eangler Botanischer Jahrbücher VI. Str. 287.

- Plavšić S. 1941: Neue Pflanzenformen aus Bosnien. II. Aceraceae. Östterr. Botan. Zeitschrift Bd.90. Wien. Heft 4. Str. 213223.

- Poljak I. 2014: Morfološka i genetička raznolikost populacija i kemijski sastav plodova europskog pitomog kestena (Castanea sativa Mill.) u Hrvatskoj. Doktorska disertacija. Šumarski fakultet Sveučilišta u Zagrebu, str. 1-194. Zagreb.
- Poljak I., M. Idžojtić, I. Šapić, J. Vukelić, M. Zebec 2014: Population variability of grey (Alnus incana /L./ Moench) and black alder (A. glutinosa /L./ Gaertn.) in the Mura and Drava region according to the leaf morphology. Šumarski list, 138 (1-2): 7-17.

- Poljak I., M. Idžojtić, M. Zebec, N. Perković 2012: The variability of European sweet chestnut (Castanea sativa Mill.) in the region of northwest Croatia according to morphology of fruits. Šumarski list, 136 (9-10): 479-489. Zagreb.

- Poljak, I., D. Kajba, I. Ljubić, M. Idžojtić, 2015: Morphological variability of leaves of Sorbus domestica L. in Croatia. Acta Soc Bot Pol, 84 (2): 249-259.

- Poljak, I., M. Idžojtić, Z. Šatović, M. Ježić, M. Ćurković-Perica, B. Simovski, J. Acevski, Z. Liber, 2017: Genetic diversityof the sweet chestnut (Castanea sativa Mill.) in Central Europe and the western part of the Balkan Peninsula and evidence of marron genotype introgression into wild populations, Tree Genet Genomes, 13: 18.

- Poljak, I., M. Idžojtić, I. Šapić, P. Korijan, J. Vukelić, 2018: Diversity and Structure of Croatian Continental and Alpine-Dinaric Populations of Grey Alder (Alnus incana /L./ Moench subsp. incana): Isolation by Distance and Environment Explains Phenotypic Divergence. Šumarski List 142 (1-2): 19-32. Zagreb.

- Popović V., I. Kerkez 2016: Varijabilnost populacija divlje trešnje (Prunus avium L.) u Srbiji prema morfološkim svojstvima listova. Šumarski list, 140(7-8): 347-355. Zagreb.

- Praciak A., N. Pasiecznik, D. Sheil, M. van Heist, M. Sassen, C.S. Correia, C. Dixon, G. Fyson, K. Rushford, C. Teeling 2013: The CABI encyclopediaofforesttrees, CABI, Oxfordshire, UK.

- Savill P.S. 2013: The silviculture of trees used in British forestry. Centre for Agricultur eand Bioscience International.

- Sokal R.R., F.J. Rohlf 1981: Biometry - ThePrinciplesandPracticeofStatistics in Biological Research. 2nd ed. W.H. Freeman and Company, San Francisco.

- Šilić Č. 1990: Atlas drveća i grmlja. IP »Svjetlost«, str. 132. Sarajevo.

- Tripić R. 2011: Obrasci ekološko-morfološke diferencijacije populacija i vrsta sekcije Goniocarpa Pojárkova roda Acer na jugoistočnim Dinaridima. Doktorska disertacija. Prirodnomatematički fakultet Sarajevo. Str. 1-350. Sarajevo.

- Wright D.B., J.A. Herrington 2011: Problematic standard errors and confidence intervals. Behavior Research Methods, 43: 8-17.

- Zebec M., M, Idžojtić, I. Poljak 2014: Morfološka varijabilnost nizinskog brijesta (Ulmus minor Mill. sensu latissimo) na području kontinentalne Hrvatske. Šumarski list, 138(11-12): 563-572. Zagreb.

- Zebec M., M. Idžojtić, I. Poljak, I. Mihaldinec 2010: Varijabilnost nizinskog brijesta (Ulmus minor Mill. sensu latissimo) na području hrvatske Podravine prema morfološkim svojstvima listova. Šumarski list, 134(11-12): 569-580. Zagreb.

- Zebec, M., M. Idžojtić, I. Poljak, I. Modrić, 2015: Population variability of wychelm (Ulmus glabra Huds.) in the mountainous region of Croatia according to the leaf morphology, Šumarski list 139 (9-10): 429-439.

- Zebec, M., M. Idžojtić, Z. Šatović, I. Poljak, Z. Liber, 2016: Alive and kicking, or, living on borrowed time? - Microsatellite diversity in natural populations of the endangered Ulmus minor Mill. sensu latissimo from Croatia. Acta Bot Croat, 75 (1): 53-59. 


\section{SUMMARY}

We researched the morphological variability of 25 populations of field maple (Acer campestre L.) in the territory of Bosnia and Herzegovina. Morphometric research of intrapopulation and interpopulation variability was based on ten morphological traits of the fruit, using descriptive and univariate statistical analyses. Measured trait of fruit petiole length showed the highest variability and calculated characteristic proportion of width and length of seed showed the lowest variability. Measured traits of fruit were more variable than calculated traits, suggesting less variation in shape than the size of fruits. By analysing variance, we found statistically significant differences between populations in all analysed fruit traits. However, for most traits (eight out of nine), there was a higher intrapopulation than interpopulation variability. The obtained results can serve as a basis for further research in other parts of the species distribution range, with the aim of determining the interaction of ecological, geographical, climatic and migration factors on the overall morphological variability of field maple populations.

KEY WORDS: field maple, fruit, morphometric analysis, morphological variability

\section{PRIJE STO GODINA: ŠUMARSKI LIST 11-12/1919.}

\section{GOSPODARENJE NA MALIM POVRŠINAMA}

Završavajući ovogodišnju seriju tekstova o pisanju našeg časopisa prije sto godina ne možemo ne primijetiti da je tijekom te 1919. od prvih brojeva u novoj državi i novoj konstelaciji snaga, ispunjenih brojnim šumarsko-političkim temama, prvotni polet i oduševljenje hrvatskih šumara novim mogućnostima "bratske" suradnje jednostavno splasnuo. U posljednjem broju teško smo pronašli neku temu kojom bi se čudili našim predšasnicima i kojom ni zaintrigirali suvremenike.

Međutim, sama se otvorila jedna tema koja bi začudila te naše stare kolege: zar će se šumari i nakon sto godina još uvijek time baviti?

Hrvatsko šumarsko društvo upravo se ovih dana vratilo sa stručne ekskurzije po češkim šumama u pratnji i pod stručnim vodstvom akademika Igora Anića. Tema je bila: gospodarenje šumama na malim površinama. A pogledajte što o toj temi piše Śumarski list 11-12/1919. iz pera šumara grada Zagreba Albina Leusteka. Zapravo, izvatka iz Mayrova djela Waldbau.

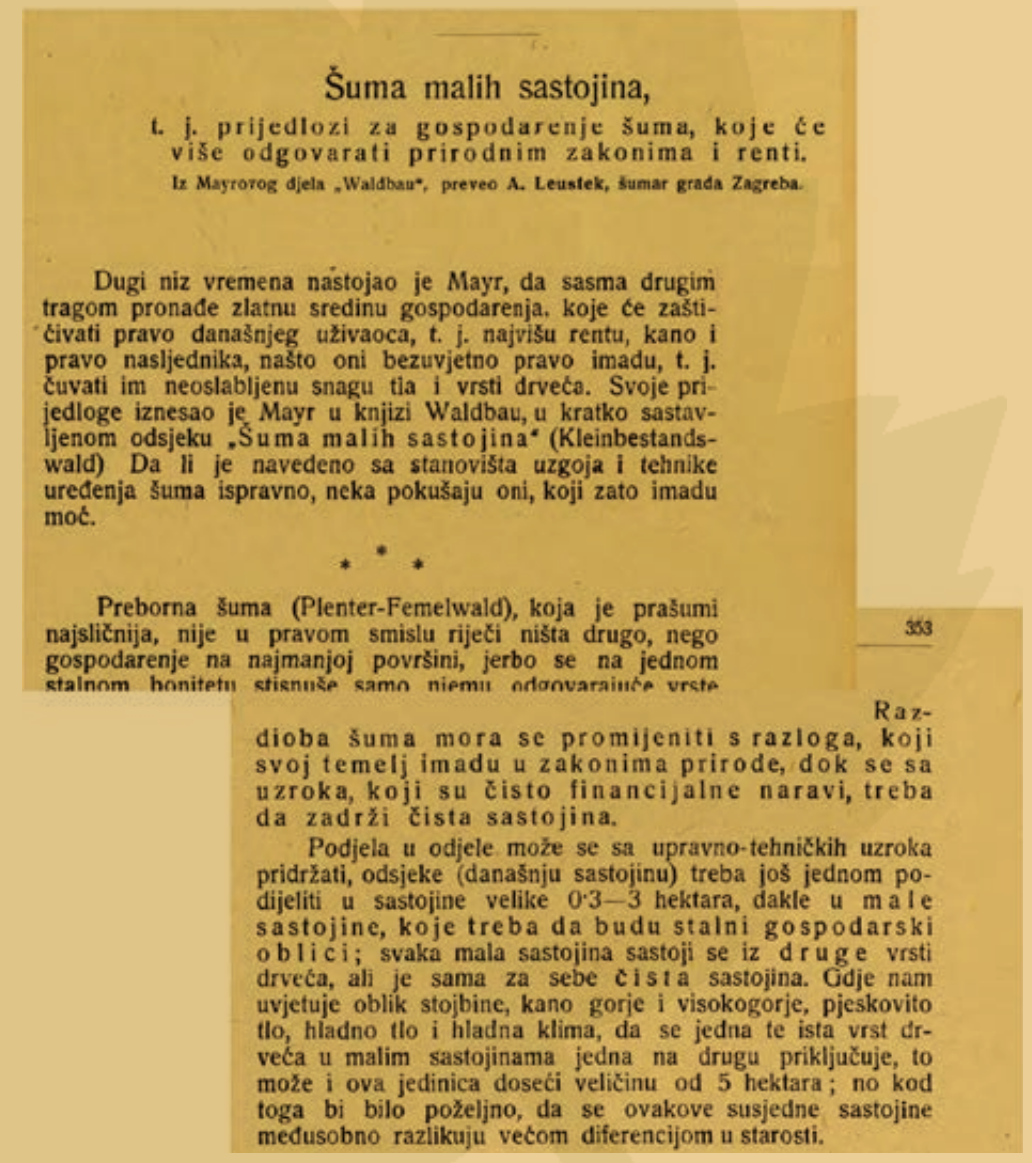

